\title{
Density-dependent productivity in a colonial vulture at two spatial scales
}

\author{
Darío Fernández-Bellon, ${ }^{1,2,5}$ Ainara Cortés-Avizanda, ${ }^{1,3}$ Rafael Arenas, ${ }^{4}$ and José Antonio Donázar ${ }^{1}$ \\ ${ }^{1}$ Department of Conservation Biology, Estación Biológica de Doñana (CSIC), Avenida Américo Vespucio, s/n 41092, Sevilla, Spain \\ ${ }^{2}$ School of Biological, Earth and Environmental Sciences, University College Cork, Distillery Fields, North Mall, Cork, Ireland \\ ${ }^{3}$ CIBIOIInBIO, Centro de Investigação em Biodiversidade e Recursos Genéticos da Universidade do Porto, Vairão, Portugal \\ ${ }^{4}$ Gestión del Medio Natural, Dirección Provincial de Córdoba, Consejería de Medio Ambiente, Junta de Andalucía, c/Tomás de \\ Aquino s/n E-14071, Córdoba, Spain
}

\begin{abstract}
Understanding how density dependence modifies demographic parameters in long-lived vertebrates is a challenge for ecologists. Two alternative hypotheses have been used to explain the mechanisms behind density-dependent effects on breeding output: habitat heterogeneity and individual adjustment (also known as interference competition). A number of studies have highlighted the importance of habitat heterogeneity in density dependence in territorial species, but less information exists on demographic processes in colonial species. For these, we expect density-dependent mechanisms to operate at two spatial scales: colony and breeding unit. In this study, we used long-term data from a recovering population of Cinereous Vultures (Aegypius monachus) in southern Spain. We analyzed a long-term data set with information on 2162 breeding attempts at four colonies over a nine-year period (2002-2010) to evaluate environmental and population parameters influencing breeding output. Our results suggest that breeding productivity is subject to density-dependent processes at the colony and the nest site scale and is best explained by interference competition. Factors intrinsic to each colony, as well as environmental constraints linked to physiography and human presence, also play a role in regulatory processes. We detected the existence of a trade-off between the disadvantages of nesting too close to conspecifics and the benefits of coloniality. These could be mediated by the agonistic interactions between breeding pairs and the benefits derived from social sharing of information by breeding individuals. We propose that this trade-off may play a role in defining colony structure and may hold true for other colonial breeding bird species. Our findings also have important management implications for the conservation of this threatened species.
\end{abstract}

Key words: Aegypius monachus; breeding success; Cinereous Vulture; coloniality; density dependence; habitat heterogeneity; interference competition; population regulation; productivity.

\section{INTRODUCTION}

Understanding the processes shaping and regulating the dynamics and size of animal populations has been an on-going pursuit of ecology (Caughley 1994, Hixon et al. 2002). Density dependence is one of the issues attracting most attention from ecologists, due to the key role it plays in modeling breeding rates and survival across a range of taxa including plant, invertebrate, and vertebrate species (Goldberg et al. 2001, Sergio and Newton 2003, Boggs and Inouye 2012). Two hypotheses have been invoked to explain the mechanisms behind density-dependent breeding output: the habitat heterogeneity hypothesis $(\mathrm{HHH})$ and the individual adjustment hypothesis (IAH, also referred to as interference competition; see Grünkorn et al. 2014). The HHH propounds that increasing breeding

Manuscript received 24 February 2015; revised 1 July 2015; accepted 25 August 2015. Corresponding Editor: J. R. Sauer

${ }^{5}$ E-mail: dfernandezbellon@gmail.com densities lead to the saturation of optimal breeding sites. New breeding units are then forced to occupy inferior quality habitats where breeding output is lower. While this does not reduce the breeding rate of all pairs, it does increase the proportion of low-quality sites with lower breeding output (Sergio and Newton 2003). On the other hand, the IAH suggests that increasing densities lead to higher frequencies of agonistic conspecific interactions and competition between breeding units. A key difference is that this process affects all individuals equally, resulting in reductions in the breeding rates of all pairs (Sillett et al. 2004).

Growing evidence suggests that the $\mathrm{HHH}$ adequately explains density-dependent breeding output in territorial species (Gaillard et al. 1993, Coltman et al. 1999, Carrete et al. 2006, Krüger et al. 2012). However, information on colonial species is limited and has focused mainly on seabirds (Ashbrook et al. 2010, Szostek et al. 2014, Oppel et al. 2015). Some studies 
suggest that the IAH may play a preponderant role in these species: in growing colonies, breeding rates may be affected by increased competition for food resources in foraging areas (Fernández et al. 1998, Tella et al. 2001) or by increased conspecific interactions in breeding areas (e.g., agonistic interactions at nest sites between breeding pairs; Bretagnolle et al. 2008). However, in colonial species these mechanisms may operate at different spatial scales, complicating the detection of density dependence. Interactions between conspecifics may occur between specific breeding units within a colony (e.g., at the nest or burrow) or between all individuals of the colony (e.g., in overlapping foraging areas). Thus, density dependence may occur at the breeding unit scale, at the colony scale, or at both scales simultaneously. In this context, multiscale approaches evaluating the factors relevant at each scale enable detection of these processes and allow for a comprehensive understanding of their underlying causes (Ray and Hastings 1996, Rogers and Schindler 2011).

Here we study the effects of density dependence on long-term breeding output in a semi-colonial avian scavenger at two spatial scales: colony and nest site. Our study model was the Cinereous Vulture (Aegypius monachus), a globally near-threatened species (BirdLife International 2015) that breeds in loose colonies. Data covered a nine-year period of a monitoring program at four Cinereous Vulture colonies in Andalusia (southern Spain) where the population has been protected for four decades. This protection led to a significant decline in human interference and substantial demographic growth (Dobado et al. 2012), providing a unique opportunity to study natural demographic processes, as human-related factors were no longer expected to be the main driving force of population trends.

We aimed to determine the response of Cinereous Vulture breeding productivity to changes in conspecific densities at both the colony and nest site scale. We also assessed the relative contribution of environmental factors highlighted as important by previous research. First, at the colony scale, a common prediction arises for the IAH and HHH: long-term changes in productivity will be driven by variations in density of conspecifics. Proximate factors would be linked to saturation of potential breeding sites within the colony or to changes in colony structure and relative position of nests. Second, at the nest site scale, we expect that if the IAH is operating, nests located close to each other (i.e., with higher rates of conspecific interactions) will experience reduced breeding success. Also, according to the IAH, we expect that newly established breeding pairs will have similar productivity to older breeding units (as nest site habitat would not play a role in influencing fecundity). Conversely, under the $\mathrm{HHH}$ we would expect nest site habitat, and not proximity to neighbors, to determine changes in productivity.

\section{Methods}

Study species and area

The Cinereous Vulture is a large avian scavenger whose colonies may hold up to hundreds of pairs, with nests separated by distances ranging from a few meters to several kilometers (Cramp and Simmons 1980, Dobado et al. 2012). Monogamous pairs build a nest on the top of large trees (usually oaks or conifers) in areas with low human presence (Donázar et al. 2002, Margalida et al. 2011). A single egg is laid and the chick fledges after 50-60 days of incubation and 120 days of development (Cramp and Simmons 1980). The species is found from the Iberian Peninsula to central Asia and has gone extinct or suffers on-going declines in many parts of its range (BirdLife International 2015).

Our study was conducted in Andalusia, southern Spain, where throughout the study period $200-300$ pairs bred in four distinct colonies in the Sierra Morena mountain range: Sierra Pelada, Sierra Norte, Sierra de Hornachuelos, and Sierra de Andújar (hereafter referred to as S. Pelada, S. Norte, S. Hornachuelos, and S. Andújar; see Fig. 1). Colonies occupy areas ranging from 200 to $750 \mathrm{~m}$ above sea level where climate is semi-continental Mediterranean (Donázar et al. 2002). Vegetation cover is a matrix of forested areas (mainly evergreen oaks) and dehesa-type habitats (open landscapes dominated by Mediterranean scrubland with scattered woodland patches and isolated trees). The westernmost colony (S. Pelada, see Fig. 1) has been transformed since the 1950s for forestry exploitation purposes: up to $70 \%$ of the colony is covered by plantations of eucalyptus (Eucalyptus sp.), stone pines (Pinus pinea), and maritime pines ( $P$. pinaster; Donázar et al. 2002). Currently, all Cinereous Vulture nest sites in Andalusia lie within protected lands (82\%) or within $5 \mathrm{~km}$ from the nearest protected area $(18 \%)$. Although human disturbance and persecution were considered an important cause of nest failure in the past (Donázar et al. 2002, Dobado et al. 2012), public education and protection of breeding areas has contributed to diminishing the influence of these factors on the Andalusian population (Dobado et al. 2012).

\section{Field procedures and data collection}

From 2002 to 2010, Cinereous Vulture colonies were monitored during the breeding season between December and August. In the early part of the season (December-April), monthly visits were made to check for occupation of previously known sites and to locate new sites by observing courting behavior of adult birds. Tree nest species and a GPS location was recorded for all nests located. Active nests were monitored for the remainder of the season (May-August) with visits every two weeks to determine breeding outcome. 


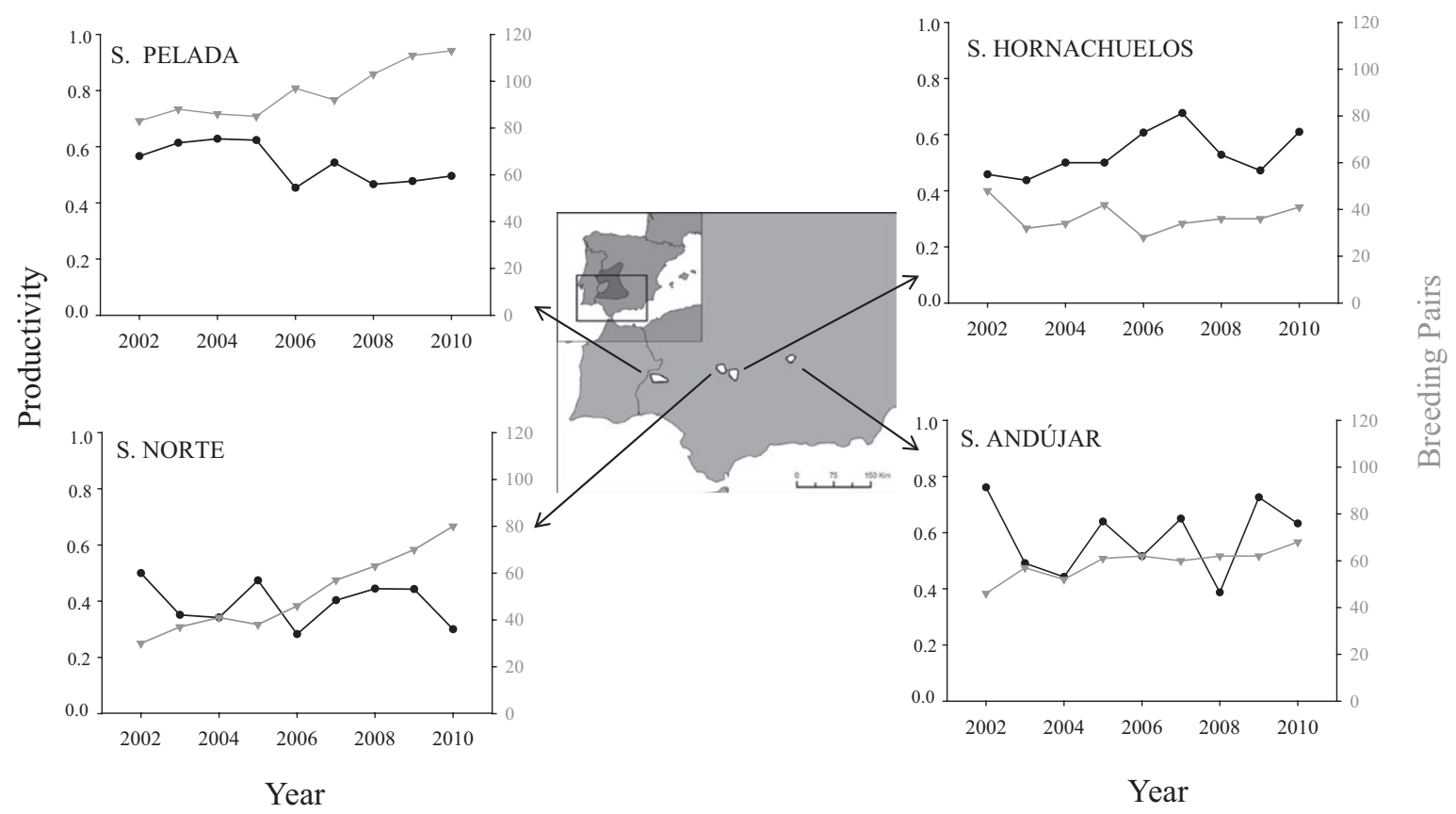

FIG. 1. Iberian distribution of the Cinereous Vulture (after De la Puente et al. 2007) and location of the four study colonies in Andalusia; productivity (black dots) and number of breeding pairs (gray triangles) at each colony during the study period (20022010).

Observations were carried out with $60 \times$ telescopes at distances $>300 \mathrm{~m}$ to avoid disturbing breeding birds.

For the purposes of this study, nesting attempts were classified as successful (fledging confirmed) or failed (all nests where pairs were observed in attendance but which failed to fledge a chick). Cinereous Vultures bred on 726 different nest platforms between 2002 and 2010: S. Pelada $(n=263)$, S. Norte $(n=127)$, S. Hornachuelos $(n=134)$, and S. Andújar $(n=202)$. Reuse of nest sites by breeding pairs during the study period resulted in a data set with information on 2162 breeding attempts.

\section{Variable selection}

Nest sites were mapped using ArcGIS 10 software (ESRI, Redlands, California, USA), in combination with Geospatial Modeling Environment (available online) ${ }^{6}$ and DEM Surface Tools (available online) $)^{7}$ to determine values for physiography, vegetation, human disturbance, and population explanatory variables (Table 1 and Appendix S1: Tables S1 and S2). For calculation of nest site variables, a $500 \mathrm{~m}$ radius buffer around each nest platform was defined as the area of influence on the nest (Margalida et al. 2011). An initial selection of explanatory variables was made based on current knowledge of Cinereous Vulture breeding

\footnotetext{
${ }^{6}$ www.spatialecology.com/gme

${ }^{7}$ www.jennessent.com
}

requirements (weather, physiography, land use, human disturbance) and evaluators of breeding density (Cramp and Simmons 1980, Donázar et al. 2002, Carrete et al. 2007, Dobado et al. 2012, Guerrero-Casado et al. 2013, Moreno-Opo et al. 2013). In order to avoid colinearity and nonindependence of variables, Spearman correlation coefficients were calculated for all variable pairs; those with values of $|r|>0.7$ were considered redundant and one of the variables was consequently excluded from further analyses (Dormann et al. 2013; see Table 1 for the final set of variables used at both scales).

\section{Colony scale analyses: density dependence}

Models were built firstly to test for differences in productivity between colonies and to assess the importance of environmental factors. The best model of this set was then used as a base model to evaluate the importance of different population parameters (Table 2). The response variable for all models at the colony scale was productivity per colony and year (Colony productivity). This variable was calculated as the proportion of successful nests to the total number of occupied nests (successful/(successful + failed); values ranging between 0 and 1). The first set of models (colony environment models, $\mathrm{Ce}$ ) included the explanatory variable Colony fitted as a factor to test for differences in productivity between the studied colonies (model $\mathrm{Cel}$ ). A variable reflecting yearly variations in weather that could influence Cinereous Vulture 
TABLE 1. Response and explanatory variables used in analyses of Cinereous Vulture productivity at colony and nest site scales in Andalusia during the study period (2002-2010).

\begin{tabular}{|c|c|c|}
\hline Variable & Description and calculation & Data source \\
\hline \multicolumn{3}{|l|}{ COLONY SCALE } \\
\hline Colony productivity & $\begin{array}{l}\text { colony productivity ([no. successful nests]/[no. failed + no. } \\
\text { successful nests]) }\end{array}$ & fieldwork \\
\hline Colony & breeding colony & fieldwork \\
\hline Rain & mean daily rainfall $(\mathrm{mm})$ between February and July & IIFAP (2012) \\
\hline Saturation & $\begin{array}{l}\text { percentage of colony saturation ([no. nests]/[maximum no. nests } \\
\text { recorded during the study]) }\end{array}$ & fieldwork \\
\hline Colony SocEnv & colony social environment (mean Nest SocEnv index) & GIS \\
\hline \multicolumn{3}{|c|}{ NEST SITE SCALE } \\
\hline Nest productivity & nest productivity (failed [0] or successful [1]) & fieldwork \\
\hline \multicolumn{3}{|l|}{ Vegetation } \\
\hline Tree & tree species on which the nest platform was built & fieldwork \\
\hline Dominant & dominant tree species in $500 \mathrm{~m}$ radius around the nest & GIS, vegetation cover (SIOSE 2011) \\
\hline$\%$ ConOak & percent cover of conifers and oaks in $500 \mathrm{~m}$ radius around the nest & GIS, vegetation cover (SIOSE 2011) \\
\hline$\%$ Shrub & percent cover of shrubs in $500 \mathrm{~m}$ radius around the nest & GIS, vegetation cover (SIOSE 2011) \\
\hline \multicolumn{3}{|l|}{ Physiography } \\
\hline Elevation & ground elevation at nest tree & GIS, digital terrain model (IGN 2010) \\
\hline Ruggedness & terrain ruggedness (SD of elevation in $500 \mathrm{~m}$ radius around the nest) ${ }^{\dagger}$ & GIS, digital terrain model (IGN 2010) \\
\hline Aspect & slope orientation at nest tree & GIS, digital terrain model (IGN 2010) \\
\hline \multicolumn{3}{|l|}{ Human disturbance } \\
\hline Track & logarithm of distance $(\mathrm{m})$ to nearest track or road & $\begin{array}{l}\text { GIS, digital maps (ICA 2001, SCA } \\
\text { 2009, IECA 2012) }\end{array}$ \\
\hline \multicolumn{3}{|c|}{ Population parameters } \\
\hline Colony & breeding colony & fieldwork \\
\hline Neighbor & logarithm of distance $(\mathrm{m})$ to nearest active nest & GIS \\
\hline Nest SocEnv & $\begin{array}{l}\text { nest social environment }\left((i)=\sum \exp \left(-d_{i j}\right) \text {; where } i \neq j ; d_{i j} \text { is the linear }\right. \\
\text { distance between nests } i \text { and } j \text {; and } j \text { represents all active nests })^{\ddagger}\end{array}$ & GIS \\
\hline Nest Age & newly built nest site or preexisting site from previous years & fieldwork \\
\hline
\end{tabular}

Notes: Response variables are shown in boldface type. All values were calculated for each year of the study.

† See White (2006).

$\$$ See text (Colony scale analyses) and Carrete et al. (2007).

productivity was also tested in this subset (model $\mathrm{Ce}$; Rain; average daily rainfall during the core period of the breeding season from February to July) (Donázar et al. 2002, Moreno-Opo et al. 2012). The following subset of models (colony density dependence models, $\mathrm{Cd}$, in Table 2) was based on model $\mathrm{Ce} 3$ and tested the existence of density dependence by contrasting the importance of different population parameters. Changes in colony productivity could be linked to increased saturation of potential breeding sites within the colony (model $C d I$ ). This variable (Saturation) was calculated annually as the proportion of occupied nests to the maximum number of nests recorded at the colony during the whole study period. Although this metric is similar to the number of active nests in the colony (with which it is correlated), it has the advantage of allowing comparison of densities between colonies that might differ in carrying capacity. Finally, we tested the role of changes in colony structure and relative position of nests (e.g., tighter packing of nests; model $C d 2$ ). To this end, we used a measure of the colony's social environment (Colony SocEnv). This is based on an individual nest index (Nest SocEnv) used to describe the relative position of each nest within the spatial distribution of all other nests (Carrete et al. 2007). Values of Nest SocEnv are negatively related to isolation (range $0-1$, from more isolated to more connected nests) and were defined by Nest SocEnv $v_{i}=\Sigma \exp \left(-d_{i j}\right)$; where $i \neq j ; d_{i j}$ is the linear distance between nests $i$ and $j$; and $j$ represents all active nests (Carrete et al. 2007). Colony SocEnv was calculated as the mean of all Nest SocEnv values in a given year at each colony. Different values of Colony SocEnv would therefore reflect changes in colony structure, which might, in turn, influence productivity.

\section{Nest site scale analyses: individual adjustment and habitat heterogeneity hypotheses}

Nest site scale analyses followed a similar approach to that used at the colony scale: we contrasted models testing the relative importance of environmental factors described by previous research as relevant at this scale, and used the best model obtained to construct models testing our hypotheses on density dependence. The response variable was productivity per nest and year 
TABLE 2. Generalized linear mixed models developed to investigate density-dependent productivity in Cinereous Vultures in Andalusia during the study period (2002-2010).

\begin{tabular}{|c|c|c|c|c|}
\hline $\begin{array}{l}\text { Response and random } \\
\text { variables, model } \mathrm{ID}^{\dagger}\end{array}$ & Model & AICc/AIC & $\Delta \mathrm{AICc} / \Delta \mathrm{AIC}$ & Model weights \\
\hline \multicolumn{5}{|c|}{ Colony productivity (Year) } \\
\hline $\mathrm{Ce} 1$ & Colony & 231.9 & 5.2 & 0.069 \\
\hline $\mathrm{Ce} 2$ & Rain & 258.2 & 31.5 & 0.000 \\
\hline $\mathrm{Ce} 3$ & Colony + Rain & 226.7 & 0 & 0.931 \\
\hline $\mathrm{Cd} 1$ & Colony + Rain + Saturation & 223.2 & 0.9 & 0.374 \\
\hline $\mathrm{Cd} 2$ & Colony + Rain + Colony SocEnv & 227.7 & 5.4 & 0.039 \\
\hline $\mathrm{Cd} 3$ & Colony + Rain + Saturation + Colony SocEnv & 222.3 & 0 & 0.587 \\
\hline \multicolumn{5}{|c|}{ Nest productivity (Year, Nest site) } \\
\hline $\mathrm{Ne} 1$ & $\begin{array}{l}\text { Colony }+ \text { Tree }+ \text { Dominant }+\% \text { Shrub }+ \text { Elevation } \\
\quad+\text { Ruggedness }+ \text { Track }\end{array}$ & 2413.9 & 0.8 & 0.215 \\
\hline $\mathrm{Ne} 2$ & $\begin{array}{l}\text { Colony + Tree + Dominant }+\% \text { ConOak + Elevation } \\
\quad+\text { Ruggedness }+ \text { Track }\end{array}$ & 2415.1 & 2 & 0.117 \\
\hline $\mathrm{Ne} 3$ & $\begin{array}{l}\text { Colony + Tree + Dominant + Elevation + Ruggedness } \\
\quad+\text { Track }\end{array}$ & 2413.1 & 0 & 0.320 \\
\hline $\mathrm{Ne} 4$ & $\begin{array}{l}\text { Colony }+ \text { Tree }+ \text { Dominant }+\% \text { Shrub }+ \text { Ruggedness } \\
+ \text { Track }\end{array}$ & 2414.7 & 1.6 & 0.144 \\
\hline $\mathrm{Ne} 5$ & Colony + Tree + Dominant + Ruggedness + Track & 2414.0 & 0.9 & 0.204 \\
\hline Nd1 & $\begin{array}{l}\text { Colony }+ \text { Tree }+ \text { Dominant }+ \text { Ruggedness }+ \text { Track } \\
+ \text { Neighbor }\end{array}$ & 2412.8 & 1.6 & 0.202 \\
\hline $\mathrm{Nd} 2$ & $\begin{array}{l}\text { Colony + Tree + Dominant + Ruggedness + Track } \\
+ \text { Nest SocEnv }\end{array}$ & 2415.5 & 4.3 & 0.052 \\
\hline $\mathrm{Nd} 3$ & $\begin{array}{l}\text { Colony }+ \text { Tree }+ \text { Dominant }+ \text { Ruggedness }+ \text { Track } \\
+ \text { Nest Age }\end{array}$ & 2415.9 & 4.7 & 0.043 \\
\hline $\mathrm{Nd} 4$ & $\begin{array}{l}\text { Colony }+ \text { Tree }+ \text { Dominant }+ \text { Ruggedness }+ \text { Track } \\
+ \text { Neighbor }+ \text { Nest SocEnv }\end{array}$ & 2411.2 & 0 & 0.448 \\
\hline $\mathrm{Nd} 5$ & $\begin{array}{l}\text { Colony }+ \text { Tree }+ \text { Dominant }+ \text { Ruggedness }+ \text { Track } \\
++ \text { Neighbor }+ \text { Nest Age }\end{array}$ & 2414.7 & 3.5 & 0.078 \\
\hline Nd6 & $\begin{array}{l}\text { Colony + Tree + Dominant + Ruggedness + Track } \\
+ \text { + Nest SocEnv + Nest Age }\end{array}$ & 2417.4 & 6.2 & 0.020 \\
\hline $\mathrm{Nd} 7$ & $\begin{array}{l}\text { Colony }+ \text { Tree }+ \text { Dominant }+ \text { Ruggedness }+ \text { Track } \\
+ \text { Neighbor }+ \text { Nest SocEnv }+ \text { Nest Age }\end{array}$ & 2413.3 & 2.1 & 0.157 \\
\hline
\end{tabular}

Notes: Model sets test environmental factors (Ce models at the colony scale, Ne models at the nest site scale), and population parameters indicative of density dependence ( $\mathrm{Cd}$ models at the colony scale, $\mathrm{Nd}$ models at the nest site scale). At the nest site scale, only the five best environmental models $(\mathrm{Ne})$ are shown due to the large number of variables fitted. Following lowest AICc/AIC and model parsimony criteria, models selected in each set were Ce3, Cd1, Ne5 and Nd4. Significant factors $(P<0.05)$ are shown in boldface type. AIC, Akaike Information Criterion; AICc, AIC corrected for sample size. ${ }^{\dagger}$ First variable is the response variable, random variables are shown in parenthesis.

(Nest Productivity); with a value of one for nests where fledging was confirmed (successful) and a value of zero for all other occupied nests (failed). First we evaluated models containing habitat, physiography, and human disturbance variables highlighted as important by previous research (see Table 1 for description of variables, Table 2 for a list of the five lowest Akaike Information Criterion (AIC) nest environment models tested, $\mathrm{Ne}$ [Donázar et al. 2002, Moreno-Opo et al. 2012, 2013, Guerrero-Casado et al. 2013]). As other non-evaluated factors could be involved in determining productivity (Symonds and Moussalli 2011), we also included the colony in which a nest was located (Colony) as a factor.

As several nest environment models had similar AIC values ( $\triangle$ AIC $<2$; Burnham and Anderson 2002), we selected the most parsimonious model fitted with only significant variables (model Ne5). Building on this model we tested density dependence to discern between the IAH and the HHH. The IAH was evaluated by fitting variables that would reflect interactions between nesting pairs (models $N d 1$ and $N d 2$ ). Thus, the distance to the nearest active nest (Neighbor) was used as a measure of direct agonistic interactions between pairs (Stokes and Boersma 2000) whereas Nest SocEnv (see above, Colony scale analyses) was used to reflect the relative position of each nest to all other nests within the colony. The HHH was evaluated by assessing the potential existence of differences in quality of nest sites (model $N d 3$ ). If habitat heterogeneity played an important role in our study population, we would expect new pairs to occupy low-quality sites while the best sites would be occupied by established pairs, which had bred in previous years. Although it was not possible to identify individual birds in our study, Cinereous Vultures are known to reuse nest sites (Cramp and Simmons 1980), allowing us to use the age of the 
nest as a proxy for potential variations in nesting habitat quality (Sergio and Newton 2003). Therefore, we used the variable Nest Age to differentiate between new nests occupied by newly established pairs (which, according to the $\mathrm{HHH}$, would correspond to suboptimal sites) and preexisting nests built in previous years occupied by older breeding units (high-quality sites, according to the $\mathrm{HHH}$; Cramp and Simmons 1980). Models with different combinations of these variables were also contrasted (models $N d 4-N d 7$ ).

\section{Modeling procedures}

Analyses were carried out by means of Generalized Linear Mixed Models (GLMM; Littell et al. 2006). Response variables were proportions (at the colony scale) and binary (at the nest site scale), thus the appropriate error distribution was binomial (link function: logit). To avoid nonindependence of data, the nest site (at nest site scale) and year (at both scales) were included as random terms. This allowed us to account for effects associated with nest site (such as pair effects) and yearly fluctuations, which could otherwise not be measured. Missing values ( $n=1$ at colony scale; $n=233$ at nest site scale) were excluded in order to maintain constant sample size and enable model comparison (Symonds and Moussalli 2011). AIC at the nest site scale and smallsample corrected AIC (AICc) at the colony scale were calculated for all models. Model weights were calculated for each set (colony and nest site scale) following Burnham and Anderson (2002). All statistical analyses were performed with R 3.2.0 (R Core Team 2015).

\section{RESULTS}

Between 2002 and 2010, notable growth in breedingpair numbers was registered at three of the four colonies (Fig. 1). S. Norte experienced the most dramatic population increase $\left(139 \% ; r_{\mathrm{S}}=0.972, P<0.001\right.$, $n=9)$, followed by $\mathrm{S}$. Andújar $\left(48 \% ; r_{\mathrm{S}}=0.861\right.$, $P=0.001, n=9)$ and S. Pelada $\left(36 \% ; r_{\mathrm{S}}=0.917\right.$, $P<0.001, n=9$ ). In $\mathrm{S}$. Hornachuelos, changes in breeding-pair numbers were not significant. Long-term significant changes in productivity were only apparent in S. Pelada, where productivity decreased throughout the study period $\left(r_{\mathrm{S}}=-0.617, P=0.077, n=9\right.$; $P>0.15$ in the three other colonies).

At both scales, models revealed that Cinereous Vulture productivity was associated with variables measuring density dependence. At the colony scale, the lowest AICc and most parsimonious model ( $C d l$, Tables 2 and 3) showed productivity to be negatively associated with Saturation, indicating that colonies had lower breeding outputs in years when the number of breeding pairs approached maximum occupation. Changes in colony structure (Col SocEnv, model Cd2 and $C d 3$ ) were nonsignificant and did not appear to affect productivity at the colony scale. At the nest site scale, the best model was indicative of densitydependent processes by the IAH (model $N d 4$, including variables Neighbor and Nest SocEnv; Tables 2 and 3). Distance to the nearest active nest (Neighbor) was positively related to productivity, indicating that pairs breeding close to another active nest were more likely to fail. On the other hand, the positive relationship between Nest SocEnv and productivity suggests that nests that were "better connected" to all other nests in the colony had higher productivity values. These results reveal a trade-off between two counteracting pressures: distance to the nearest active nest and relative position within the colony (Fig. 2). Although both variables influence productivity simultaneously, they do so unequally; distance to the nearest neighbor has a greater effect on breeding output. Summary and mean values for response and predictor variables can be found in Appendix S1 (Tables S1 and S2).

At the nest site scale, environmental variables evaluating physiography, vegetation, and human disturbance also played a role in explaining variations in productivity. Productivity was associated with the species of nest tree (Tree), with nests on conifer or oak trees suffering reduced productivity compared to nests in other tree species. Similarly, surrounding tree cover (Dominant) indicated no differences between nests surrounded by oaks or by conifers, but higher productivity values for nests surrounded by other tree species (mainly Eucalyptus sp. or deciduous species). In addition, productivity was negatively related to Ruggedness. This indicates that successful nests were more likely to be found in less rugged terrain. Finally, nests located further from tracks (Track), and thus subjected to lower disturbance levels, registered higher productivity.

It is worth noting that, at both scales, the variable Colony was highly significant in explaining productivity. This variable showed a recurrent pattern across all models: S. Norte was consistently associated with much lower breeding outputs. In the three remaining colonies (S. Pelada, S. Hornachuelos and S. Andújar), productivity was intermediate or high (with no significant or only marginally significant differences between these colonies).

\section{Discussion}

Our results show that density-dependent processes affect productivity in the Cinereous Vulture at both scales analyzed and conforms to the IAH. At the colony scale, higher Saturation values resulted in a density-dependent decline in productivity. Interference competition at this scale could be acting either by depletion of resources or by generalized intraspecific agonistic encounters (Bretagnolle et al. 2008). Cinereous Vultures are central-place foragers, with individuals from the same colony foraging in overlapping areas at large distances $(>50 \mathrm{~km})$ from nests 
TABLE 3. Generalized linear mixed models selected to explain Cinereous Vulture productivity in relation to density dependence at colony and nest site scale in Andalusia during the study period (2002-2010).

\begin{tabular}{|c|c|c|c|}
\hline Model, response variable, explanatory variables & Estimate & SE & Significance \\
\hline \multicolumn{4}{|l|}{ Cd1, Colony productivity } \\
\hline Intercept & 1.206 & 0.369 & \\
\hline \multirow[t]{4}{*}{ Colony $(\mathrm{SA} \sim \mathrm{SP}>\mathrm{SH}>>>\mathrm{SN})$} & SA 1.206 & 0.369 & ns \\
\hline & $\mathrm{SP}-0.150$ & 0.120 & ns \\
\hline & $\mathrm{SH}-0.248$ & 0.153 & $*$ \\
\hline & $\mathrm{SN}-0.911$ & 0.154 & $* * *$ \\
\hline Rain & -0.060 & 0.099 & ns \\
\hline Saturation & -0.947 & 0.412 & * \\
\hline \multicolumn{4}{|l|}{ Nd4, Nest productivity } \\
\hline Intercept & -0.621 & 1.011 & \\
\hline \multirow[t]{4}{*}{ Colony (SA $\sim \mathrm{SH} \sim \mathrm{SP}>>>\mathrm{SN}$ ) } & SA -0.138 & 0.224 & ns \\
\hline & $\mathrm{SP}-0.710$ & 0.311 & ns \\
\hline & $\mathrm{SH}-0.621$ & 1.011 & ns \\
\hline & $\mathrm{SN}-0.715$ & 0.205 & $* * *$ \\
\hline \multirow[t]{3}{*}{ Tree (Others » Quercus $\sim$ Pinus) } & Others -0.621 & 1.011 & ns \\
\hline & Pinus -1.291 & 0.713 & $*$ \\
\hline & Quercus -1.869 & 0.735 & $*$ \\
\hline \multirow[t]{3}{*}{ Dominant (Others » Quercus $\sim$ Pinus) } & Others -0.621 & 1.011 & ns \\
\hline & Pinus -0.669 & 0.196 & $*$ \\
\hline & Quercus -0.628 & 0.267 & $*$ \\
\hline Ruggedness & -0.009 & 0.005 & $*$ \\
\hline Track & 0.498 & 0.154 & $* *$ \\
\hline Neighbor & 0.440 & 0.178 & $*$ \\
\hline Nest SocEnv & 3.977 & 2.105 & $*$ \\
\hline
\end{tabular}

Note: SP, Sierra Pelada; SN, Sierra Norte; SH, Sierra de Hornachuelos; SA, Sierra de Andújar. $* P<0.05 ; * * P<0.001$; $* * * P<0.0001 ; \mathrm{ns}=$ not significant. For relationship between categorical variables, $>$ refers to significance of $P<0.05 ;>>$ to $P<0.001 ;>>>$ to $P<0.0001 ; \sim$ to nonsignificant differences.

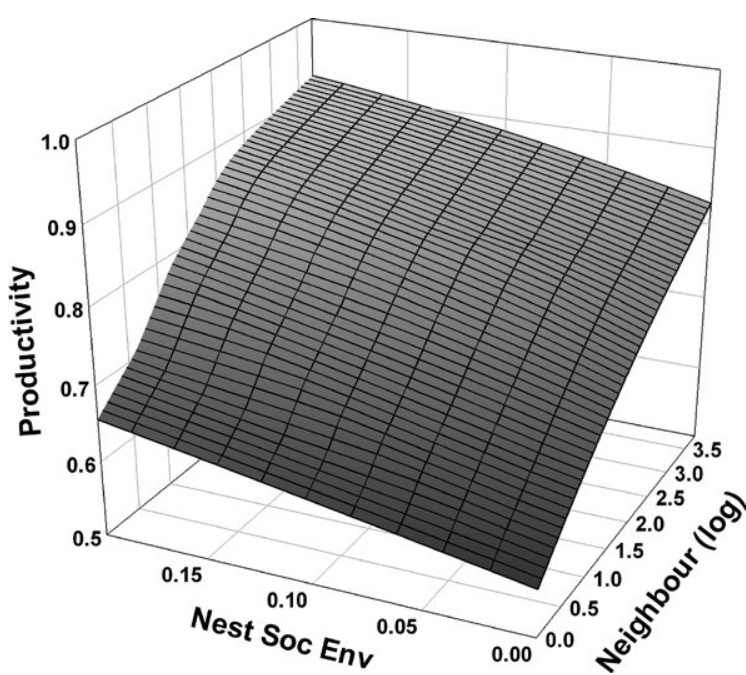

FIG. 2. Graphical representation of the trade-off between distance to the nearest neighboring nest (Neighbor) and a nest's social environment (Nest SocEnv) and the effect of these parameters on Cinereous Vulture nest productivity. The variable measuring the nest's social environment ranges from zero to one (from lower to higher connectivity of a nest to all other nests in the colony). This projection is based on model Nd4 (nest site productivity, Table 2) and uses default estimates from $\mathrm{S}$. Pelada for all other fitted variables.
(Carrete and Donázar 2005, Dobado et al. 2012). An increase in colony breeding density would lead to higher densities in foraging areas and potentially to higher levels of competition and depletion of food resources. This effect has been described in seabird colonies (Ashmole's halo; Ashmole 1963, Wakefield et al. 2013, Oppel et al. 2015) but has also been observed in colonial raptors (Bonal and Aparicio 2008). Limitation of food in foraging areas can ultimately have detrimental effects on colony productivity (Tella et al. 2001, Forero et al. 2002). On the other hand, as breeding pair numbers and colony density increase, so does the frequency of interactions between nesting pairs (Bretagnolle et al. 2008). Frequent agonistic interactions between breeding pairs could affect incubation, brooding and feeding rates or stress levels of breeding birds, with negative consequences for breeding output (Forero et al. 2006).

At the more localized nest site scale, best models clearly supported the IAH and did not include factors indicative of the HHH. Two factors indicating interference competition (Neighbor and Nest SocEnv) were significant, while the factor Nest Age, which would indicate differences in nest site quality (and support the $\mathrm{HHH}$ ), was nonsignificant and did not appear in 
the best models. Small nearest neighbor distances (Neighbor) indicative of frequent agonistic interactions resulted in lower productivity (supported by field observations of frequent aggressive interactions between pairs nesting in close proximity [E. Luque, personal communication]). However, nests that were well connected to the rest of the colony (high Nest SocEnv values) had higher breeding output. Although these results may initially appear contradictory, these variables measure different aspects of a nest's spatial ecology: nearest neighbor distance (Neighbor) serves as an indicator of frequency of agonistic interactions, while Nest SocEnv measures the position of the nest within the colony, which may be associated with benefits derived from individuals' access to public information regarding quality of foraging areas (Danchin et al. 2004, Deygout et al. 2010, Wakefield et al. 2013). When considered jointly, they suggest the existence of a trade-off between the costs and benefits of nesting close to conspecifics (Fig. 2). However, the slope associated with each variable in Fig. 2 indicates that direct conspecific interference at nest sites is more important as a driving force of productivity in this species (i.e., changes in the value of distance to neighbor are linked to larger variations in productivity). Furthermore, the effects of conspecific interference on productivity (particularly at short distances between nests) may play a role in determining the loose colonial breeding structure of Cinereous Vultures. The benefits of coloniality (such as shared information) would be outweighed by the costs (agonistic interactions) for pairs nesting at close quarters, resulting in colonies where nests are spaced well apart. We propose that this trade-off may hold true for other loosely colonial or semi-colonial bird species. How these selective pressures, along with other costs and benefits of coloniality (e.g., mate choice, extra pair copulation, predator detection, group defense [Møller 1987, Danchin et al. 1998]) determine individual recruitment and fitness is a matter that deserves close attention in future finescale research on the adaptive value of coloniality.

At both scales, an important source of variation in breeding output was associated with the explanatory variable Colony. These results suggest that factors that were not assessed by our study and that vary between colonies were influencing productivity. Closer inspection of the variation in productivity reveals that $\mathrm{S}$. Norte had the lowest productivity and that S. Pelada was the only colony to register a significant decrease in productivity during the study period. Several factors, which may act in combination, could be behind these trends. In these two colonies, large numbers of immature Cinereous and Griffon Vultures (Gyps fulvus) are present year-round (Dobado et al. 2012; P. Dobado and E. Luque, personal communication). The presence of nonbreeding individuals can play an important role in population productivity by increasing interference at nest sites (Carrete et al. 2006, Bretagnolle et al.
2008) or competition for food resources as floaters gain access to social information on foraging areas (Deygout et al. 2010). Observations of frequent agonistic interactions between nesting pairs and immature vagrants in S. Norte corroborate this interpretation (E. Luque, personal communication). In the case of S. Pelada, the recorded decrease in productivity may also be influenced by on-going forestry exploitation activities that, despite increased protection, expose breeding birds to relatively higher levels of disturbance than in other colonies (Donázar et al. 2002).

At the nest site scale, productivity was also related to vegetation cover, physiography, and human disturbance factors. Both the nest tree (Tree) and dominant tree species surrounding the nest (Dominant) had a significant effect on productivity. However, previous work has shown that nest-tree selection in Cinereous Vultures is not species specific but related to the size and structure of the tree and the surrounding vegetation (Donázar et al. 2002, Moreno-Opo et al. 2012, 2013). In this study, only S. Pelada has areas dominated by Eucalyptus and deciduous species, while tree cover in the other three colonies is homogenously limited to oaks and conifers. This leads us to conclude that the link between tree species and productivity may in fact be a spurious relationship ascribable to the particular vegetation features within S. Pelada colony and the low productivity registered there. Models also showed that nests located in terrain that is not excessively rugged (Ruggedness) were more likely to succeed in fledging young. This was in line with findings from previous studies, and is probably related to the species' flight requirements (Donázar et al. 2002, Moreno-Opo et al. 2012). It is interesting to note that human disturbance (measured by the distance to the nearest track, Track) is still a relevant factor affecting productivity in Andalusia, despite increased protection and control of human activities in breeding areas for four decades (Margalida et al. 2011, Dobado et al. 2012). Long-term persistence of evasive behaviors, despite the disappearance of negative effects associated with human presence, can be expected in a long-lived species and may help explain these findings (Donázar et al. 2002, Parks et al. 2007, Linhart et al. 2012).

Our results reinforce the idea that density dependence in colonial bird species could be mostly determined by interference competition (Fernández et al. 1998, Tella et al. 2001, Bretagnolle et al. 2008). This may be explained by the relative homogeneity of nesting habitat within colonies and by shared foraging areas, in comparison to the spatially structured heterogeneity typical of territorial species. Furthermore, as predation is a minor issue for this species, colonies do not display the nest site quality gradient reported for smaller colonial birds whose nests are more likely to be predated if they are located in the colony periphery (Gilchrist 1999, Massaro et al. 2001). It follows from 
this that the prevalence of density-dependent demographic processes based on the HHH or the IAH may be species specific in relation to life-history strategies. This specificity would be related not only to the species' coloniality, but also to other aspects such as the degree of individual sociability (which may vary with age and thus affect spatial segregation) and to the importance of public information in determining foraging strategies. In this scenario, it is possible to envisage changes in productivity as the result of a combination of both processes $(\mathrm{HHH}$ and IAH; Grünkorn et al. 2014).

An important result from our research is the positive effect of connectivity (the nests' social environment) on productivity. This finding highlights the adaptive value of nesting near conspecifics. In this case the benefits would not be related to defense against predators as occurs in small body-sized colonial birds (Serrano et al. 2005), but perhaps to increased foraging efficiency as a consequence of shared information. Similar patterns have been observed in other social vertebrates exploiting spatially and temporally unpredictable resources (Wakefield et al. 2013, Cortés-Avizanda et al. 2014). This raises the question: could the advantages of connectivity between nests vary with colony size? Optimal values of connectivity could be related to intermediate-sized colonies: in small colonies, foraging efficiency would be compromised, while, in large colonies, the potential benefits of increased connectivity would be outweighed by interference competition. Research on colonial species at a metapopulation scale will be necessary to shed light on this aspect.

\section{Conclusions and conservation implications}

Overall, our study highlights the importance of multi-scale approaches and suggests that productivity in colonial species may be affected by more factors than those reported by previous studies. Our results reveal that the interaction between a nest's position within the colony and its distance to the nearest neighbor lead to a trade-off between the benefits (shared information) and costs (agonistic interactions) of colonial breeding. Nest productivity would thus be optimized at locations that minimize the frequency of interactions with other pairs, while still remaining well positioned within the colony to profit from access to shared information. However, this relationship may be confounded by other environmental factors that can impose strong spatial constraints (e.g., nest tree availability, ruggedness). The presence and the abundance of nonbreeding conspecifics (Carrete et al. 2006), as well as the numbers of individuals of competing scavenger species (Griffon Vultures in this case) may further obscure regulatory processes. In conclusion, understanding density-dependent productivity goes far beyond the simple examination of factors related to the proximity between reproductive units. Multi-scale interactions between the study species and physical and biological factors should also be considered. Discerning what variation in productivity is ascribable to environment factors and/or to individual breeding strategies may be a major future challenge.

Our results also have relevant implications for the long-term conservation of this endangered species. We highlight that for successful breeding, pairs require a large area that allows the distance between nests to be maximized, while staying within a range that permits pairs to benefit from colonial behavior. Consequently, long-term viable Cinereous Vulture colonies would require huge areas of land meeting certain requirements for hosting breeding pairs. Otherwise, nest site shrinkages may lead to declines in breeding output and reduced population viability. How these needs fit with changes to the European landscape in the next century (Navarro and Pereira 2012, Cortés-Avizanda et al. 2015) should be a research priority, particularly as the conservation strategy for large scavengers often involves the restoration of viable metapopulations by means of costly conservation measures such as reintroductions (Hirzel et al. 2004, Margalida et al. 2013).

\section{ACKNOWLEDGMENTS}

We would like to thank the Agencia de Medio Ambiente y Agua de Andalucía (Consejería de Agricultura, Pesca y Medio Ambiente) for the authorization to use Cinereous Vulture data sets. P. Dobado-Berrios and J. R. Benítez were of great help with data management and their deep knowledge of the Andalusian vulture colonies. P. Dobado-Berrios, E. Luque, L. Cardenete, F. Díaz, and P. Martínez were responsible for colony monitoring. M. de la Riva, F. J. Hernández Fernández, D. Serrano, O. Lapiedra, C. O'Toole, M. Carrete, N. Fernández, P. Jordano, and R. Díaz Delgado were of great assistance in different phases of this study. J. Sauer and two anonymous referees provided helpful and constructive comments on earlier drafts. This work was funded thanks to an agreement between the Agencia de Medio Ambiente y Agua (Consejería de Agricultura, Pesca y Medio Ambiente, Junta de Andalucía), the Doñana Biological Station (CSIC), and Project CGL2012-40013-C02-01. A. Cortés-Avizanda was supported by a post-doctoral grant from the Fundação para a Ciência e a Tecnologia (FCT) (SFRH/BPD/91609/2012).

\section{Literature Cited}

Ashbrook, K., S. Wanless, M. P. Harris, and K. C. Hamer. 2010. Impacts of poor food availability on positive density dependence in a a highly colonial seabird. Proceedings of the Royal Society B-Biological Sciences 277:2355-2360.

Ashmole, N. P. 1963. The regulation of numbers of tropical oceanic birds. Ibis 103:458-473.

BirdLife International. 2015. Species factsheet: Aegypius monachus. http://www.birdlife.org.

Boggs, C. L., and D. W. Inouye. 2012. A single climate driver has direct and indirect effects on insect population dynamics. Ecology Letters 15:502-508.

Bonal, R., and J. M. Aparicio. 2008. Evidence of prey depletion around lesser kestrel Falco naumanni colonies and its short 
term negative consequences. Journal of Avian Biology 39:189-197.

Bretagnolle, V., F. Mougeot, and J. C. Thibault. 2008. Density dependence in a recovering osprey population: demographic and behavioural processes. Journal of Animal Ecology 77:998-1007.

Burnham, K. P., and D. R. Anderson. 2002. Model selection and multimodel inference: a practical information-theoretic approach, 2nd edition. Springer, New York, New York, USA.

Carrete, M., and J. A. Donázar. 2005. Application of centralplace foraging theory shows the importance of Mediterranean dehesas for the conservation of the Cinereous Vulture, Aegypius monachus. Biological Conservation 126:582-590.

Carrete, M., J. A. Donázar, and A. Margalida. 2006. Densitydependent productivity depression in Pyrenean bearded vultures: implications for conservation. Ecological Applications 16:1674-1682.

Carrete, M., J. M. Grande, J. L. Tella, J. A. Sánchez-Zapata, J. A. Donázar, R. Díaz-Delgado, and A. Romo. 2007. Habitat, human pressure, and social behavior: partialling out factors affecting large-scale territory extinction in an endangered vulture. Biological Conservation 136:143-154.

Caughley, G. 1994. Directions in conservation biology. Journal of Animal Ecology 63:215-244.

Coltman, D. W., J. A. Smith, D. R. Bancroft, J. Pilkington, A. D. C. MacColl, T. H. Clutton-Brock, and J. M. Pemberton. 1999. Density-dependent variation in lifetime breeding success and natural and sexual selection in Soay rams. American Naturalist 154:730-746.

Cortés-Avizanda, A., R. Jovani, J. A. Donázar, and V. Grimm. 2014. Bird sky networks: how do avain scavengers use social information to find carrion? Ecology 95:1799-1808.

Cortés-Avizanda, A., J. A. Donázar, and H. M. Pereira. 2015. Top scavengers in a wilder Europe. Pages 85-106 in H. M. Pereira, and L. N. Navarro, editors. Rewilding European landscapes. Springer, London.

Cramp, S., and K. E. L. Simmons. 1980. Handbook of the birds of Europe, the Middle East and north Africa. The birds of the western Palearctic. Volume 2: Hawks to bustards. Oxford University Press, Oxford, London, UK \& New York, New York, USA.

Danchin, E., T. Boulinier, and M. Massot. 1998. Conspecific reproductive success and breeding habitat selection: implications for the study of coloniality. Ecology 79:2415-2428.

Danchin, E., L. A. Giraldeau, T. J. Valone, and R. H. Wagner. 2004. Public information: from nosy neighbors to cultural evolution. Science 305:487-491.

De la Puente, J., R. Moreno-Opo, and J. C. del Moral. 2007. El buitre negro en España: censo nacional (2006). SEO/BirdLife, Madrid, Spain.

Deygout, C., A. Gault, O. Duriez, F. Sarrazin, and C. BessaGomes. 2010. Impact of food predictability on social facilitation by foraging scavengers. Behavioral Ecology 21:1131-1139.

Dobado, P. M., M. A. Díaz-Portero, L. García, E. Luque, J. Martín, P. Martínez, and R. M. Arenas. 2012. El buitre negro Aegypius monachus en Andalucía (España). Pages 13-37 in P. M. Dobado, and R. M. Arenas, editors. The black vulture: status, conservation and studies. Consejería de Medio Ambiente de la Junta de Andalucía, Sevilla, Spain.

Donázar, J. A., G. Blanco, F. Hiraldo, E. Soto-Largo, and J. Oria. 2002. Effects of forestry and other land-use practices on the conservation of Cinereous Vultures. Ecological Applications 12:1445-1456.

Dormann, C. F., et al. 2013. Collinearity: a review of methods to deal with it and a simulation study evaluating their performance. Ecography 36:27-46.
Fernández, C., P. Azkona, and J. A. Donázar. 1998. Densitydependent effects on productivity in the griffon vulture Gyps fulvus: the role of interference and habitat heterogeneity. Ibis 140:64-69.

Forero, M. G., J. L. Tella, K. A. Hobson, M. Bertellotti, and G. Blanco. 2002. Conspecific food competition explains variability in colony size: a test in Magellanic penguins. Ecology 83:3466-3475.

Forero, M. G., J. González-Solis, J. M. Igual, K. A. Hobson, X. Ruiz, and G. Viscor. 2006. Ecological and physiological variance in T-cell mediated immune response in Cory's shearwaters. Condor 108:865-876.

Gaillard, J. M., D. Delorme, J. M. Boutin, G. Vanlaere, B. Boisaubert, and R. Pradel. 1993. Roe deer survival patterns: a comparative analysis of contrasting populations. Journal of Animal Ecology 62:778-791.

Gilchrist, H. G. 1999. Declining thick-billed murre Uria lomvia colonies experience higher gull predation rates: an inter-colony comparison. Biological Conservation $87: 21-29$.

Goldberg, D. E., R. Turkington, L. Olsvig-Whittaker, and A. R. Dryer. 2001. Density dependence in an annual plant community: variation among life history stages. Ecological Monographs 71:423-446.

Grünkorn, T., A. Potiek, V. Looft, R. M. Jonker, N. Chakarov, and $\mathrm{O}$. Krüger. 2014. Territory quality affects the relative importance of habitat heterogeneity and interference competition in a long-lived territorial songbird. Journal of Avian Biology 45:15-21.

Guerrero-Casado, J., R. Arenas, and F. S. Tortosa. 2013. Modelling the nesting-habitat of the Cinereous Vulture Aegypius monachus on a fine scale for conservation purposes. Bird Study 60:533-538.

Hirzel, A. H., B. Posse, P. A. Oggier, Y. Crettenand, C. Glenz, and R. Arlettaz. 2004. Ecological requirements of reintroduced species and the implications for release policy: the case of the bearded vulture. Journal of Applied Ecology 41:1103-1116.

Hixon, M. A., S. W. Pacala, and S. A. Sandin. 2002. Population regulation: historical context and contemporary challenges of open vs. closed systems. Ecology 83:1490-1508.

ICA. 2001. Instituto de Cartografía de Andalucía: CD mapa de Andalucía vectorial 1:10000. Junta de Andalucía, Spain.

IECA. 2012. Instituto de Estadística y Cartografía de Andalucía, Junta de Andalucía: servicio de descargas de mapas y ortofotografías de Andalucía. http://www.juntadeandalucia.es/ institutodeestadisticaycartografia/.

IGN. 2010. Instituto Geográfico Nacional, Ministerio de Fomento: modelo digital de terreno 05. http://centrodedescargas.cnig.es/CentroDescargas/.

IIFAP. 2012. Instituto de Investigación y Formación Agraria y Pesquera, Junta de Andalucía: estaciones agroclimáticas. http://www.juntadeandalucia.es/agriculturaypesca/ifapa/ria/ servlet/FrontController.

Krüger, O., N. Chakarov, J. T. Nielsen, V. Looft, T. Grünkorn, B. Struwe-Juhl, and A. P. Møller. 2012. Population regulation by habitat heterogeneity or individual adjustment? Journal of Animal Ecology 81:330-340.

Linhart, P., R. Fuchs, S. Polakova, and H. Slabbekoorn. 2012. Once bitten twice shy: long-term behavioural changes caused by trapping experience in willow warblers Phylloscopus trochilus. Journal of Avian Biology 43:186-192.

Littell, R. C., G. A. Milliken, W. W. Stroup, R. D. Wolfinger, and O. Schabenberger. 2006. SAS for mixed models, 2nd edition. SAS Institute, Cary, North Carolina, USA.

Margalida, A., R. Moreno-Opo, B. E. Arroyo, and A. Arredondo. 2011. Reconciling the conservation of endangered species with 
economically important anthropogenic activities: interactions between cork exploitation and the Cinereous Vulture in Spain. Animal Conservation 14:167-174.

Margalida, A., M. Carrete, D. Hegglin, D. Serrano, R. Arenas, and J. A. Donázar. 2013. Uneven large-scale movement patterns in wild and reintroduced pre-adult bearded vultures: conservation implications. PLoS ONE 8:e65857.

Massaro, M., J. W. Chardine, and I. L. Jones. 2001. Relationships between black-legged kittiwake nest site characteristics and susceptibility to predation by large gulls. Condor 103:793-801.

Møller, A. P. 1987. Advantages and disadvantages of coloniality in the swallow, Hirundo rustica. Animal Behaviour $35: 819-832$.

Moreno-Opo, R., M. Fernández-Olalla, A. Margalida, A. Arredondo, and F. Guil. 2012. Effect of methodological and ecological approaches on heterogeneity of nest-site selection of a long-lived vulture. PLoS ONE 7:e33469.

Moreno-Opo, R., M. Fernández-Olalla, A. Margalida, A. Arredondo, and F. Guil. 2013. Influence of environmental factors on the breeding success of Cinereous Vultures Aegypius monachus. Acta Ornithologica 48:187-193.

Navarro, L. M., and H. M. Pereira. 2012. Rewilding abandoned landscapes in Europe. Ecosystems 15:900-912.

Oppel, S., et al. 2015. Foraging distribution of a tropical seabird supports Ashmole's hypothesis of population regulation. Behavioral Ecology and Sociobiology 69:915-926.

Parks, S. E., C. W. Clark, and P. L. Tyack. 2007. Short- and long-term changes in right whale calling behavior: the potential effects of noise on acoustic communication. Journal of the Acoustical Society of America 122:3725-3731.

R Core Team. 2015. R: A language and environment for statistical computing. R Foundation for Statistical Computing, Vienna, Austria. http://www.R-project.org/.

Ray, C., and A. Hastings. 1996. Density dependence: are we searching at the wrong spatial scale? Journal of Animal Ecology 65:556-566.

Rogers, L. A., and D. E. Schindler. 2011. Scale and the detection of climatic influences on the productivity of salmon populations. Global Change Biology 17:2546-2558.
SCA. 2009. Sistema Cartográfico de Andalucía: CD DEA 100 datos espaciales de Andalucía para escalas intermedias. Junta de Andalucía, Spain.

Sergio, F., and I. Newton. 2003. Occupancy as a measure of territory quality. Journal of Animal Ecology 72:857-865.

Serrano, D., D. Oro, E. Ursua, and J. L. Tella. 2005. Colony size selection determines adult survival and dispersal preferences: Allee effects in a colonial bird. American Naturalist 166:E22-E31.

Sillett, T. S., N. L. Rodenhouse, and R. T. Holmes. 2004. Experimentally reducing neighbor density affects reproduction and behavior of a migratory songbird. Ecology $85: 2467-2477$

SIOSE. 2011. Sistema de Información de Ocupación del Suelo de España, Ministerio de Fomento: SIOSE 2005. http://www.juntadeandalucia.es/medioambiente/site/web/ rediam/.

Stokes, D. L., and P. D. Boersma. 2000. Nesting density and reproductive success in a colonial seabird, the Magellanic penguin. Ecology 81:2878-2891.

Symonds, M. R. E., and A. Moussalli. 2011. A brief guide to model selection, multimodel inference and model averaging in behavioural ecology using Akaike's information criterion. Behavioral Ecology and Sociobiology 65:13-21.

Szostek, K. L., P. H. Becker, B. C. Meyer, S. R. Sudmann, and H. Zintl. 2014. Colony size and not nest density drives reproductive output in the common tern Sterna hirundo. Ibis 156:48-59.

Tella, J. L., M. G. Forero, M. Bertellotti, J. A. Donázar, G. Blanco, and O. Ceballos. 2001. Offspring body condition and immunocompetence are negatively affected by high breeding densities in a colonial seabird: a multiscale approach. Proceedings of the Royal Society B-Biological Sciences 268:1455-1461.

Wakefield, E. D., et al. 2013. Space partitioning without territoriality in gannets. Science 341:68-70.

White, K. S. 2006. Seasonal and sex-specific variation in terrain use and movement patterns of mountain goats in southeastern Alaska. Pages 183-193 in B. Wishart, and M. Pybus, editors. Biennial symposium of the northern wild sheep and Goat council. NWSGC, Cody, Wyoming, USA.

\section{SUPPORTING INFORMATION}

Additional supporting information may be found in the online version of this article at http://onlinelibrary.wiley.com/ doi/10.1890/15-0357.1/suppinfo 